\title{
DOPAD TRANSFORMÁCIE POLNOHOSPODÁRSTVA A VSTUPU SLOVENSKA DO EURÓPSKEJ ÚNIE NA ŠTRUKTÚRU PRACOVNÝCH SÍL
}

\author{
Jana Némethová, Petra Jad’ud'ová
}

\begin{abstract}
The article is focused on analysing the impact of the transformation of agriculture in 1989 to employment in this sector in Slovakia. The changes that have occurred in the various structures of the labour force are related not only to the significant decline of workers in the year 1999, in particular, they relate to age and educational structure of employees. In another part of the article, the impact of the Slovakia entry into the European Union (EU) is monitored on employment in agriculture, which brought a slow-down of the decline in the number of employees. In comparison with the year 2001, the age structure of the population has worsened in recent years. The agricultural population is steadily growing older and the share of employees in the lower age groups is shrinking. The level of qualification of agricultural employees is increasing. Cooperatives are characterized by the most significant employment. In the issue of the support of the employment in agriculture in Slovakia, is necessary to promote more projects aimed at improving the age structure of the workers, to support young start-up farmers and also to support the rural diversification.
\end{abstract}

Keywords: employment in agriculture, transformation of agriculture, impact of Slovakia entry to the European Union, structures of labour force, rural diversification

\section{Úvod}

V príspevku sledujeme dopad transformačného procesu a vstupu Slovenska do Európskej únie na zamestnanost' v pol'nohospodárstve v Slovenskej republike. Skúmanie zamestnanosti patrí medzi najdôležitejšie témy analýz agrárnej ekonomiky. V príspevku sa zaoberáme ukazovatel'mi štruktúry zamestnanosti podl'a pohlavia, veku, vzdelania a pracovného zaradenia. Pol'nohospodárstvo už nie je dominantným hospodárskym odvetvím vidieka, i napriek tomu má významnú úlohu v produkcii kvalitných potravín, v údržbe krajiny, poskytuje pracovné miesta pre vidiecke obyvatel'stvo. Pol'nohospodárstvo má však pre spoločnost' nenahraditel'nú úlohu v podobe zabezpečovania výživy obyvatel'stva. Z toho vyplýva, že jeho produkčná funkcia je najdôležitejšia. V súčasnosti v ekonomike vidieka významnú rolu získavajú malé a stredné podniky, rodinné podniky spracovatel'ského priemyslu, mladí farmári a renesancia remesiel, čo 
smeruje k diverzifikácii ekonomických činnosti, ktorá prináša viac pracovných príležitostí pre obyvatel'stvo vidieka.

Ciel'om príspevku je predstavit' zmeny ktoré nastali $\mathrm{v}$ zamestnanosti v pol'nohospodárstve Slovenska v súvislosti s procesom transformácie po roku 1989 a vstupom SR do Európskej únie (EÚ) v roku 2004, kedy sa krajina prispôsobila Spoločnej pol’nohospodárskej politike (SPP) štátov EÚ. V príspevku teda skúmame dopad týchto dvoch procesov na štruktúru pracovných síl v pol'nohospodárstve.

\section{Teoreticko-metodické východiská problematiky}

Zamestnanost'ou v pol'nohospodárstve sa vo svojich príspevkoch komplexne zaoberá Buchta $(2013,2015)$. Podl'a neho znižovanie stavov pracovných síl v pol'nohospodárstve je sprievodným javom kontinuálnej reštrukturalizácie agrárneho sektoru. Podl'a Jamborovej a Masára (2015) vývoj agrárnej zamestnanosti na Slovensku charakterizuje nielen pokles pracujúcich, ale i podielové zmeny v postavení v zamestnaní, v zastúpení profesijných kategórií, $\mathrm{v}$ štruktúre pracujúcich $\mathrm{z}$ hl'adiska pohlavia, veku, vzdelania a rast počtu nezamestnaných pracovníkov s posledným zamestnaním v pol'nohospodárstve, tzv. agrárna nezamestnanost'. Počet pracovných síl v pol’nohospodárstve trvale klesá pri raste technologického vybavenia výroby a raste výkonov (Szabo, Grznár, 2015). V súlade $\mathrm{s}$ Valachom a Balážovej (2013) do roku 1990 plnilo pol'nohospodárstvo z celospoločenského hl'adiska významnú sociálnu funkciu, najmä v oblasti zamestnanosti vidieckych regiónov SR. Vstup SR do EÚ nezastavil klesajúci trend zamestnanosti v pol'nohospodárstve. SPP sa snaží rôznymi formami zamestnanost' $\mathrm{v}$ pol'nohospodárstve udržat', napr. dotácie pre mladých pol'nohospodárov, ale nízka mzda, neatraktívnost' tohto odvetvia k zvyšovaniu zamestnanosti neprispievajú (Věžník et. al., 2017). Dopadmi vstupu Slovenska do EÚ na pol'nohospodárstvo Slovenska a tiež na pracovnú silu v pol’nohospodárstve sa zaoberajú vo svojom príspevku Némethová, Dubcová, Kramáreková (2014) a Némethová (2006), ktorá rieši danú problematiku v Nitrianskom kraji. Pol'nohospodárstvo postupne stráca svoje dominantné postavenie vo vidieckom prostredí a následne tak vzniká potreba hl'adat' možné prepojenia s inými výrobnými i nevýrobnými odvetviami. Do popredia sa dostáva naviazanie agrárneho sektoru na cestovný ruch a vznik agroturistiky (Spišiak a kol., 2005). K zachovaniu určitého rozmeru pol'nohospodárstva bude nutné udržat' život a aktivity na vidieku, vytvárat' nové pracovné miesta a podporovat' zapojenie mladých l’udí do pol’nohospodárstva (Věžník, Svobodová, 2012).

Práve sociálna funkcia $\mathrm{v}$ pol'nohospodárstve Slovenska bude centrom pozornosti príspevku, ked'že $\mathrm{v}$ sebe zahŕňa pracovné pozície pre obyvatel'stvo vidieka. Pracovná sila spolu s kapitálom a pôdou tvoria kl’účové výrobné faktory, ktoré zabezpečujú výsledok každého pol’nohospodárskeho podniku. 
K spracovaniu príspevku sme použili štatistické dáta z publikácií ako sú Štrukturálny cenzus fariem z rokov 2001 a 2010. Ďalej sme informácie čerpali zo ŠÚ SR - Štruktúry zamestnancov v pol’nohospodárstve 2004-2016. Pracovali sme aj so Správami o pol’nohospodárstve a potravinárstve SR (Zelenými správami) za roky 2000-2016. Využili sme tiež interné materiály ŠÚ SR v Bratislave. K dosiahnutiu ciel'a sme použili hlavne metódu komparatívnu a analýzy. Štatistické dáta sme spracovali do tabuliek, vyhodnotili ich vývoj indexom, kartograficky sme poukázali na vývojové tendencie a súčasný stav skúmanej problematiky.

\section{Dopad transformácie pol'nohospodárstva, po roku 1989, na zamestnanost' v pol'nohospodárstve}

Situácia v SR pred rokom 1989 nedovol'ovala existenciu nezamestnanosti a preto pre agrárny sektor bola charakteristická vysoká prezamestnanost'. Vyplýva to nielen $\mathrm{z}$ toho, že $\mathrm{v}$ pol’nohospodárstve boli zamestnané marginálne sociálne skupiny - to znamená tá čast' práceschopnej populácie, ktorá nemala žiadne iné možnosti pracovného uplatnenia a tak vel'mi ojedinelý status ,nezamestnanej osoby“ v tom období prinútil zamestnat' aj osoby s nižším vzdelaním, staršie skupiny či sociálne slabších obyvatel'ov. V pol’nohospodárstve sa v tomto období rozšírili nepol'nohospodárske činnosti tzv. pridružené výroby (Némethová, 2006).

Príčiny vysokej zamestnanosti môžeme hladat' aj $v$ nedostatočne vybudovanej ekonomickej infraštruktúre na vidieku a už uvedené pridružené výroby, väčšinou dobre fungujúce pri pol'nohospodárskych družstvách absorbovali značnú čast' miestnej populácie, ktorá nenašla uplatnenie $\mathrm{v}$ iných odvetviach a zároveň táto činnost' zlepšovala ekonomiku pol'nohospodárskeho podniku (Jamborová, Masár, 2005).

Pracovná sila, ktorá bola $\mathrm{v}$ tom období zamestnaná $\mathrm{v}$ agrárnom sektore, bola najmenej kvalifikovaná $\mathrm{v}$ porovnaní $\mathrm{s}$ ostatnými odvetviami národného hospodárstva a taktiež sa tu nachádzalo vel'ké množstvo pracovníkov, ktorí boli v preddôchodkovom či dôchodkovom veku a tiež sociálne neprispôsobiví zamestnanci, ktorí nenašli uplatnenie $\mathrm{v}$ iných oblastiach. Zavádzajúce zmeny hlavne $\mathrm{v}$ uplatňovaní nových technológií či postupov a inovácií, pri ktorých sa prejavil tlak na zvýšenie kvality pracovníkov v pol'nohospodárstve, v mnohých prípadoch priniesol postupné prepúšt’anie.

Transformácia rastlinnej výroby znamenala znižovanie výmery osiatej plochy, zmenu v štruktúre využitia ornej pôdy, zníženie hektárových úrod viacerých plodín, orientáciu na trhové plodiny (olejniny) a postupný útlm živočíšnej výroby sa prejavili na klesaní počtu predovšetkým manuálnych a obslužných pracujúcich. Práve v tomto období začína postupná zmena štruktúry hrubého domáceho produktu (HDP) a zamestnanosti v prospech sektoru služieb. Podiel primárneho sektora na celkovej zamestnanosti v národnom hospodárstve 
v roku 1995 už dosiahol hodnotu len 5,1 \%, čo v porovnaní s rokom 1989 je zníženie počtu pracovníkov o $50 \%$.

Výrazný úbytok pracovníkov nastáva $\mathrm{v}$ agrárnom sektore hlavne do roku 1999 (v roku 1989 bolo zamestnaných 350956 pracovníkov, v roku 1999 už len 92 291), potom je pokles pracovníkov miernejší (tab. 1). V roku 1994 predstavoval podiel zamestnaných $\mathrm{v}$ pol'nohospodárstve na celkovej zamestnanosti Slovenska $10,2 \%$, v štátoch EÚ-15 to bolo v tomto období 5,3\%. Vel'kú zmenu pozorujeme $\mathrm{v}$ jednotlivých právnych formách pol'nohospodárskych subjektov, hlavne v štátnych podnikoch, čo je samozrejme spôsobené vznikom súkromného vlastníctva. V štátnych podnikoch do roku 1999 nastal prudký pokles zamestnancov. Pri porovnaní rokov 1989 a 2000 poklesla zamestnanost' v pol'nohospodárstve o $99,7 \%$. V družstvách poklesla zamestnanost' o $79,9 \%$, ale stále mali dominantné postavenie $\mathrm{v}$ zamestnanosti. V porovnaní $\mathrm{s}$ ostatnými ekonomickými činnost'ami pol'nohospodárstvo zaznamenalo najvýraznejší pokles počtu pracovníkov. Znižovanie zamestnanosti sa týkalo aj ostatných odvetví národného hospodárstva. Výraznejší prísun pracovných síl, v rokoch 1989 a 2000, zaznamenalo iba finančníctvo (268,5 \%) (tab. 1).

Tab. 1: Vývoj priemerného evidenčného počtu zamestnancov vo vybraných ekonomických odvetviach v SR v rokoch 1989, 1993, 1999 a 2000

Table 1: Development of average number of registered employees in selected economic factors in SR in 1989, 1993, 1999 a 2000

\begin{tabular}{|c|c|c|c|c|c|}
\hline \multirow{2}{*}{ Odvetvie } & \multicolumn{4}{|c|}{ Priemerný evidenčný počet zamestnancov (fyzické osoby) } & \multirow{2}{*}{$\begin{array}{c}\text { Index } \\
2000 / 1989(\%)\end{array}$} \\
\hline & 1989 & 1993 & 1999 & 2000 & \\
\hline Pol'nohospodárstvo (RV a ŽV) & 350956 & 180762 & 92291 & 79384 & $-77,4$ \\
\hline družstvá & 277675 & 132958 & 64522 & 55677 & $-79,9$ \\
\hline štátne podniky & 72280 & 38937 & 471 & 222 & $-99,7$ \\
\hline Výroba potravín a nápojov & 65049 & 50643 & 47963 & 46523 & $-28,5$ \\
\hline Lesníctvo a t'ažba dreva & 40696 & 27791 & 18547 & 17727 & $-56,4$ \\
\hline Stavebníctvo & 221798 & 106055 & 69901 & 59053 & $-73,4$ \\
\hline Priemysel spolu & 727293 & 547381 & 459743 & 445433 & $-38,8$ \\
\hline Doprava a skladovanie & 158047 & 140995 & 123999 & 119036 & $-24,7$ \\
\hline Finančné a poist'. činnosti & 9484 & 19752 & 35515 & 34952 & 268,5 \\
\hline Výroba textilu & 47801 & 32151 & 18485 & 17198 & $-64,0$ \\
\hline
\end{tabular}

*(do roku 1996 v organizáciách s 25 a viac zamestnancami od roku 1997 nad 20 zamestnancov)

Zdroj: Zelená správa (2000), 2018 
Trh práce v SR sa neprispôsobil novovzniknutej situácii a neposkytol prepusteným zamestnancom v pol’nohospodárstve nové pracovné pozície. Tým vznikla agrárna nezamestnanost', čiže segment nezamestnanej populácie, ktorý mal posledné zamestnanie v pol'nohospodárstve. Ide o špecifickú skupinu pracovníkov, ktorá sa vel'mi t’ažko reintegruje do nových podmienok na trhu práce. Príčinou je ich zhoršená mobilita, nízka kvalifikačná úroveň, nevôl'a rekvalifikovat' sa a pod. (Némethová, 2006). Väčšinou išlo o pol’nohospodárske regióny južného a juhovýchodného Slovenska, v ktorých pol'nohospodárstvo zamestnávalo vysoké počty nekvalifikovaného vidieckeho obyvatel'stva.

Výrazný pokles pracujúcich v pol'nohospodárstve bol medzi rokmi 1990 a 1991, kedy medziročná zmena dosiahla (-19,6 \%) a vel'mi intenzívne klesanie pokračovalo aj do roku $1992(-19,4 \%)$, kedy bolo $\mathrm{v}$ pol'nohospodárstve zamestnaných len 211594 pracovníkov (tab. 2). V rokoch 1999, 2000 a 2001 bol počet zamestnaných menej ako 100 tis.

Tab. 2: Vývoj zamestnanosti v pol'nohospodárstve v SR v rokoch 1989 - 2001 Table 2: Development of employment in agriculture in SR in period 1989-2001

\begin{tabular}{|r|r|r|}
\hline \multirow{2}{*}{ Rok } & \multicolumn{2}{|c|}{ Ukazovatel' } \\
\cline { 2 - 4 } & počet zamestnancov v pol'nohospodárstve* & \multicolumn{1}{c|}{ medziročná zmena (\%) } \\
\hline 1989 & 360699 & $\mathbf{x}$ \\
\hline 1990 & 326660 & $-9,4$ \\
\hline 1991 & 262602 & $-19,6$ \\
\hline 1992 & 211594 & $-19,4$ \\
\hline 1993 & 178809 & $-15,5$ \\
\hline 1994 & 155699 & $-12,9$ \\
\hline 1996 & 132901 & $-8,2$ \\
\hline 1997 & 116901 & $-11,5$ \\
\hline 1998 & 105993 & $-9,3$ \\
\hline 1999 & 91545 & $-13,6$ \\
\hline 2000 & 78607 & $-14,1$ \\
\hline 2001 & 72067 & $-8,3$ \\
\hline
\end{tabular}

* (do roku 1996 nad 25 zamestnancov, od roku 1997 nad 20 zamestnancov)

Zdroj: Zelená správa (2000), 2018

V roku 2001 podl'a ŠÚ SR bolo na Slovensku trvale činných zamestnancov v pol'nohospodárstve 72067 (tab. 2) a na dohodu pracovalo iba 707 osôb. Z hl'adiska hlavnej profesie prevládala profesia trvale činní robotníci v živočíšnej výrobe (20414 pracovníkov). Trvale činných vedúcich technických a administratívnych pracovníkov bolo 13805 . Robotníkov trvale činných v rastlinnej výrobe pracovalo 11312 . 
Podiel nezamestnaných osôb $\mathrm{s}$ posledným zamestnaním v pol’nohospodárstve na celkovom počte evidovaných nezamestnaných sa znížil o $0,4 \%$ a dosiahol 6,7 \% (r. 2000). Zmenili sa prvotné ciele zamestnat' akéhokol'vek pracovníka bez ohl'adu na jeho kvalifikáciu, mzdové ohodnotenie a produktivitu. Nahradili sa novými - vytvorit' lepšie pracovné príležitosti, ktoré sú síce náročnejšie na zručnosti a znalosti zamestnancov, ale sú spojené práve $\mathrm{s}$ technologickými inováciami, vyššími mzdami a vyššou produktivitou (Buček, Borárosová, Sopkuliak, 2010). S takýmto prístupom, ktorý viac uprednostnil kvalitu pracovníkov, mohla aj nad'alej rást' pol'nohospodárska produkcia, aj ked' podniky v tomto období zamestnávali stále menej a menej pracovníkov.

Podl'a štrukturálneho cenzu fariem v roku 2001 pracovalo v pol'nohospodárstve 84291 pracovníkov. Z hl'adiska pohlavia najviac bolo zamestnaných 58004 mužov. Podl'a veku na farmách právnických osôb pracovalo viac osôb vo veku od 45 do 49 rokov (20,2 \%), iba 4,1 \% pracovníkov bolo vo veku do 24 rokov. Na celom území Slovenska prevládali v roku 2001 zamestnanci so skončeným stredoškolským vzdelaním (41 217 pracovníkov). Vzhl’adom na zastúpenie starších vekových skupín zamestnancov a tiež na menej náročné pracovné úkony, čo sa týka kvalifikácie, v agrárnom sektore vo vel'kej miere nachádzali uplatnenie aj zamestnanci so základným vzdelaním (v roku 2001 bolo zamestnaných 21922 osôb). Podla profesie pracovníkov v porovnaní so situáciou pred rokom 1989 sa do roku 2001 zmenil hlavne počet robotníkov a technickoadministratívnych pracovníkov u ktorých bola pred transformáciou pol'nohospodárstva evidovaná vysoká prezamestnanost'. Pozitívnym javom bolo postupné zvyšovanie vzdelanostnej úrovne zamestnancov, čo je dôsledkom modernejšej a vyspelejšej úrovne pol'nohospodárskej výroby, jej mechanizácie a automatizácie, ktorá si vyžaduje vy̌̌šie vzdelanie pracovníkov. Strata pracovných síl v pol'nohospodárstve Slovenska nad'alej pretrvávala i v čase jeho začleňovania do EÚ.

\section{Dopad vstupu SR do EÚ v roku 2004 na zamestnanost' v pol'nohospodárstve}

Nový charakter riadenia a politické smerovanie krajín vstupujúcich do EÚ, vlastnícke vzt’ahy, a tým aj organizačné štruktúry spoločnosti sa premietli aj do dovtedy odlišnej štátnej pol’nohospodárskej politiky. Tento proces zmien, prispôsobovania sa novým trhovým a konkurenčným podmienkam, ktoré priniesla SPP EÚ a aplikovanie moderných technológií v pol'nohospodárskej výrobe, bol v každej krajine časovo, kvalitatívne a kvantitatívne rozdielny (Buchta, 2013). Vstup Slovenska do EÚ priniesol pre SR nové možnosti, hlavne čo sa týka vývozu domácich výrobkov do zahraničia, získavanie dotácií z fondov EÚ, prácu $\mathrm{v}$ zahraničí, ale aj problémy $\mathrm{s}$ ekonomikou výroby a taktiež slabšiu konkurencieschopnost' slovenských výrobkov. To všetko sa prejavilo v obmedzení pol'nohospodárskej výroby s dopadom na jej zamestnanost'. 
V období rokov 2004 a 2017 pol’nohospodárstvo zaznamenalo viac ako $50 \%$ pokles zamestnancov. Väčší pokles $(-69,2 \%)$ sa týkal iba výroby textilu. $\mathrm{V}$ tab. 3 uvádzame porovnanie priemerného evidenčného počtu zamestnancov v pol'nohospodárstve $\mathrm{s}$ ostatnými ekonomickými činnost’ami národného hospodárstva.

Tab. 3: Vývoj priemerného evidenčného počtu zamestnancov vo vybraných ekonomických odvetviach v SR v rokoch 2004, 2007, 2010, 2013, 2016 a 2017 Table 3: Development of average number of registered employees in selected economic factors in SR in 2004, 2007, 2010, 2013, 2016 a 2017

\begin{tabular}{|c|c|c|c|c|c|c|c|}
\hline \multirow{2}{*}{ Odvetvie } & \multicolumn{6}{|c|}{ Priemerný evidenčný počet zamestnancov (fyzické osoby) } & \multirow{2}{*}{$\begin{array}{c}\text { Index } \\
2017 / 2004 \\
(\%)\end{array}$} \\
\hline & 2004 & 2007 & 2010 & 2013 & 2016 & 2017 & \\
\hline Pol’nohospodárstvo (RV a ŽV) & 51019 & 42562 & 32750 & 26703 & 26558 & 23969 & $-53,0$ \\
\hline Výroba potravín a nápojov & 38268 & 33746 & 30595 & 28315 & 29298 & 29545 & $-22,8$ \\
\hline Lesníctvo a t’ažba dreva & 9382 & 6581 & 5020 & 4850 & 5038 & 5085 & $-45,8$ \\
\hline Stavebníctvo & 45328 & 48495 & 47336 & 38205 & 35582 & 35029 & $-22,7$ \\
\hline Priemysel spolu & 416675 & 432085 & 319699 & 331202 & 364008 & 378477 & $-9,2$ \\
\hline Doprava a skladovanie & 102623 & 100644 & 90763 & 92313 & 97533 & 113345 & 10,4 \\
\hline Finančné a poist'. činnosti & 31657 & 32095 & 31553 & 31286 & 32670 & 32026 & 1,2 \\
\hline Výroba textilu & 15651 & 13863 & 4022 & 4511 & 4820 & 4825 & $-69,2$ \\
\hline
\end{tabular}

Zdroj: ŠÚ SR, 2018

V roku 2003 na Slovensku pracovalo v pol'nohospodárstve 99,4 tis. osôb, do roku 2004 sa počet pracovníkov znížil o 12,8 tis. osôb, čo predstavuje medziročnú zmenu (-10,9 \%) (Zelená správa, 2005). V roku 2004 z celkového počtu zamestnaných bolo 49938 osôb trvale činných a 31458 osôb pracovalo na dohodu. Spolu pracovalo v pol'nohospodárstve 81396 osôb (tab. 4). Z hl'adiska hlavnej profesie prevládala profesia trvale činní robotníci v živočíšnej výrobe 14033 pracovníkov. Trvale činných vedúcich technických a administratívnych pracovníkov bolo 10277 pracovníkov. Robotníkov trvale činných v rastlinnej výrobe pracovalo 8586 . Podl'a vekovej štruktúry zamestnancov v roku 2004 pracovalo najviac osôb vo vekovej kategórii 45-49 rokov (21,7 \%). Nízky podiel sa týkal zamestnancov do 24 rokov $(4,0 \%)$. Z hladiska vzdelania prevládali zamestnanci vyučení v odbore $(53,7 \%)$. Stále ešte pomerne vysoký podiel dosahovali zamestnanci so základným vzdelaním (13,8 \%). Z hl'adiska právnych foriem hospodárenia, tak ako v predchádzajúcich rokoch, najvyšší podiel agrárnej zamestnanosti vytvárali pol'nohospodárske družstvá $(67,8 \%)$ a obchodné spoločnosti sa vyznačovali $30,4 \%$ podielom na zamestnanosti. 
Od vstupu Slovenska do Európskej únie sa spomalil medziročný pokles počtu zamestnancov. Za posledných desat' rokov dochádza k poklesu počtu pracovných síl v pol'nohospodárstve Slovenska vo všetkých pracovných pozíciách. Pokles pracovných síl sa prejavil intenzívnejšie v novoprijatých štátoch ako v pôvodných štátoch Európskej únie. Na druhej strane je potrebné uviest', že nové členské štáty majú vyšší podiel pol'nohospodárstva na HDP, ale aj na zamestnanosti. V pôvodnej EÚ-15 bola miera zamestnanosti v pol'nohospodárstve zhruba $3 \%$, kým novoprijaté štáty mali tento podiel aj okolo $15 \%$ (Némethová, Dubcová, Kramáreková, 2014). Vývoj zamestnanosti v pol'nohospodárstve Slovenska je $\mathrm{v}$ súlade so štrukturálnymi zmenami, ktoré prebiehajú aj $\mathrm{v}$ ostatných štátoch EÚ. Trend znižovania počtu pracovných síl v pol'nohospodárstve je zaznamenaný vo všetkých štátoch EÚ. Napr. v štátoch V4 je vývoj podielu zamestnancov v pol'nohospodárstve na celkovej zamestnanosti nasledovný: Česká republika 4,0 \% (r. 2005) a v roku 2015 už iba 2,6 \%, Slovensko - 4,8 \% (r. 2005) a v roku 2015 - 3,4 \%, Mad'arsko - 4,9\% (r. 2005), - 4,5 \% (r. 2015), Pol'sko $17,4 \%$ (r. 2005), - 11,3 \% (r. 2015). Najvyšší podiel zamestnancov v pol'nohospodárstve v roku 2015 je okrem Pol'ska v štátoch Rumunsko - 26,4\%, Grécko - 13,2 \%, Slovinsko - 9,0 \%, Lotyšsko - 7,6 \%, Bulharsko - 6,9 \% (www.data.worldbank.org, 2018).

Do roku 2016 v porovnaní s rokom 2004 na Slovensku poklesol počet trvale činných zamestnancov o 48,7 \% a počet zamestnaných na dohodu o $65,2 \%$. Celkový pokles pracujúcich v pol’nohospodárstve predstavoval hodnotu $(-55,1 \%)$ (tab. 3)

Podl'a výsledkov ŠÚ a výsledkov Štrukturálneho cenzu fariem v roku 2010 bolo na Slovensku trvale činných zamestnancov v pol'nohospodárstve spolu 31 685. Oproti roku 2001 došlo k poklesu o 56,0 \%. Na dohodu pracovalo 22382 osôb, ich počet sa zvýšil o 21675 osôb (r. 2001 - 707 osôb). Z hl'adiska hlavnej profesie prevládala profesia trvale činní robotníci v živočíšnej výrobe 8749 pracovníkov, čo predstavuje pokles oproti roku 2001 (-57,1\%). Trvale činných vedúcich technických a administratívnych pracovníkov bolo 7019 pracovníkov (poklesli o 52,4\%). Robotníkov trvale činných v rastlinnej výrobe pracovalo 5824 $(-48,5 \%)$.

V Štrukturálnom cenze fariem 2010 - komplexné výsledky, sa informácie o jednotlivých štruktúrach pracovných síl nenachádzali, preto sme vekovú štruktúru zamestnancov v pol'nohospodárstve analyzovali na základe dát ŠÚ SR (Výberové zist'ovanie pracovných síl - Štruktúry zamestnancov rok 2015). V roku 2015 pracovalo v pol'nohospodárstve 26861 trvale činných zamestnancov a na dohodu 13 681. Pretrvávajúci pokles zamestnancov bol zaznamenaný vo všetkých profesiách. V živočíšnej výrobe bolo $\quad \mathrm{v}$ roku 2015 zamestnaných 7340 pracovníkov a v rastlinnej výrobe 5782. V sledovanom roku 2015 boli najpočetnejšími vekovými kategóriami pracujúci vo veku 55-59 rokov (20,0\%) a 50-54 rokov (15,5\%). V porovnaní s rokmi 2001 a 2004 sa veková štruktúra 
obyvatel'stva v roku 2010 zhoršila, o čom svedčí nižší podiel pracujúcich vo vekovej skupine 20-24 (2,8 \%). Čo sa týka vývoja priemerného veku zamestnancov v pol'nohospodárstve v porovnaní s rokom 1989, kedy dosiahol priemerný vek približne 41 rokov, v roku 2014 to bolo už 46,6 rokov, pričom vyšší vek dosiahla práve mužská populácia (Jamborová, Masár, 2015). Pol'nohospodárska populácia $\mathrm{v}$ posledných rokoch neustále starne a klesá podiel mladej generácie - zmenšuje sa podiel zamestnancov $\mathrm{v}$ nižších vekových skupinách a na úkor toho pribúdajú vekové kategórie najstaršie. Úbytok pracovníkov po roku 2004 bol spôsobený hlavne prirodzeným odchodom starších pracovníkov do dôchodku. Hlavnou príčinou nepriaznivej vekovej štruktúry je dlhodobý nedostatok mladších zamestnancov, ale i pokračujúci útlm hlavne živočíšnej výroby, nižšia cena vykonanej práce a situácia na trhu práce.

Tab. 3: Vývoj počtu zamestnancov v pol'nohospodárstve Slovenska v rokoch 2004 $-2016$

Table 3: Development of number of agricultural employees in Slovakia in period $2004-2016$

\begin{tabular}{|c|c|r|r|}
\hline Rok & $\begin{array}{c}\text { Počet trvale činných } \\
\text { zamestnancov }\end{array}$ & $\begin{array}{c}\text { Počet osôb pracujúcich } \\
\text { na dohodu }\end{array}$ & $\begin{array}{c}\text { Počet pracujúcich } \\
\text { spolu }\end{array}$ \\
\hline 2004 & 49938 & 31458 & 81396 \\
\hline 2005 & 48362 & 31307 & 79669 \\
\hline 2006 & 44630 & 26464 & 71094 \\
\hline 2007 & 41723 & 24987 & 66710 \\
\hline 2008 & 38370 & 24940 & 63310 \\
\hline 2009 & 35023 & 23331 & 58354 \\
\hline 2010 & 31685 & 22382 & 54067 \\
\hline 2011 & 29724 & 23772 & 53496 \\
\hline 2012 & 28835 & 22056 & 50891 \\
\hline 2013 & 28231 & 15528 & 43759 \\
\hline 2014 & 27694 & 14140 & 41834 \\
\hline 2015 & 26861 & 13681 & 40542 \\
\hline 2016 & 25595 & 10962 & 36557 \\
\hline
\end{tabular}

Zdroj: ŠÚ SR, 2017

Nad'alej zhl'adiska vzdelania je najvyšší podiel zamestnancov $\mathrm{v}$ pol'nohospodárstve vyučených $\mathrm{v}$ odbore $(45,1 \%)$. Je pozitívne, že sa znižuje podiel zamestnancov so základným vzdelaním (8,3 \% r. 2015). V porovnaní s rokom 1989 po roku 2004 viac poklesli zamestnanci s ukončeným základných vzdelaním a všeobecne sa zvýšila úroveň kvalifikácie zamestnancov agrárneho sektora. I napriek tomu je vzdelanostná štruktúra pracovných síl primárneho sektora ešte stále horšia ako v ostatných odvetviach národného hospodárstva. 
Tento sektor má stále nižší kvalifikačný potenciál. Kategória pracovníkov bez školského vzdelania sa už v agrárnom sektore nevyskytuje. Mierne sa zvyšuje podiel pracovníkov s vysokoškolským vzdelaním (Jamborová, Masár, 2015). V roku 2015 sa zvýšil podiel pracovníkov s vysokoškolským vzdelaním na 9,2 \%, v roku 2004 bol podiel týchto pracovníkov iba 6,9\%.

Vo všetkých profesiách podl'a právnych foriem subjektov bolo $\mathrm{v}$ rámci Slovenska zistené znižovanie počtu pracovníkov. Stále zostáva najviac pracovníkov zamestnaných $\mathrm{v}$ právnej forme - družstvo. Na druhej strane práve v družstvách je pokles pracovníkov výraznejší ako v ostatných typoch subjektov vo všetkých pracovných pozíciách. Napr. v roku 2004 pracovalo na družstvách 34580 zamestnancov a v roku 2015 iba 15 769. Vývoj zamestnanosti v spol. s r.o. má miernejší priebeh. Napr. v roku 2004 pracovalo v spol. s r.o. 8640 zamestnancov a v roku 2015 - 6848 . Družstvá všeobecne t’ažšie reagujú na situáciu na trhu, ked’že patria medzi väčšie podniky a nie sú tak flexibilné ako menšie obchodné spoločnosti. Na druhej strane sú stabilnejšie voči krízam a hospodárskym problémom.

Pokles zamestnancov v pol'nohospodárstve na úrovni krajov Slovenska vyjadruje mapa 1 . Vo všetkých krajoch Slovenska v sledovaných rokoch 2005, 2010 a 2016 dochádza k znižovaniu zamestnancov, pričom výraznejší pokles nastal v pol’nohospodársky najviac využívanom kraji v Nitrianskom.

Mapa 1: Vývoj počtu zamestnaných v pol’nohospodárstve v krajoch Slovenska $\mathrm{v}$ rokoch 2005, 2010 a 2016

Mapa 1: Development of number of employees in agriculture in regions of Slovakia in years of 2005, 2010 a 2016

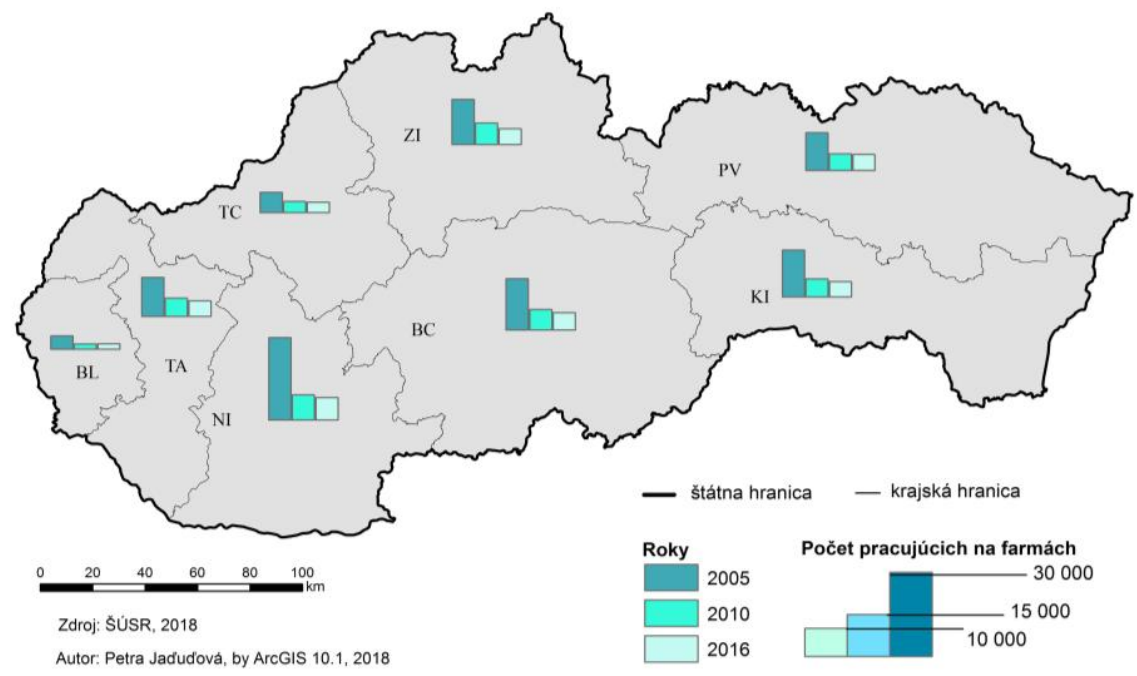


Na Slovensku sa vyššou zamestnanost'ou vyznačujú farmy právnických osôb (mapa 2). V roku 2010 na farmách právnických osôb pracovalo 42 596, do roku 2016 sa počet týchto zamestnancov znížil na 36984 (-13,2 \%). Zníženie počtu zamestnancov sa týkalo aj fariem fyzických osôb (-18,9 \%). V roku 2016 pracovalo na týchto farmách 1554 stálych zamestnancov. Pokles zamestnancov vo farmách právnických a fyzických osôb je pozorovaný aj na úrovni okresov Slovenska. Pričom výraznejší pokles je zaznamenaný vokresoch pol’nohospodársky najviac využívaných na Podunajskej a Východoslovenskej nížine (mapa 2 a 3 ).

Mapa 2: Počet stálych zamestnancov podl'a právnej formy pol'nohospodárskeho subjektu v okresoch Slovenska v roku 2010

Mapa 2: Number of permanent employees according to the legal status of agricultural subject in districts of Slovakia in year 2010

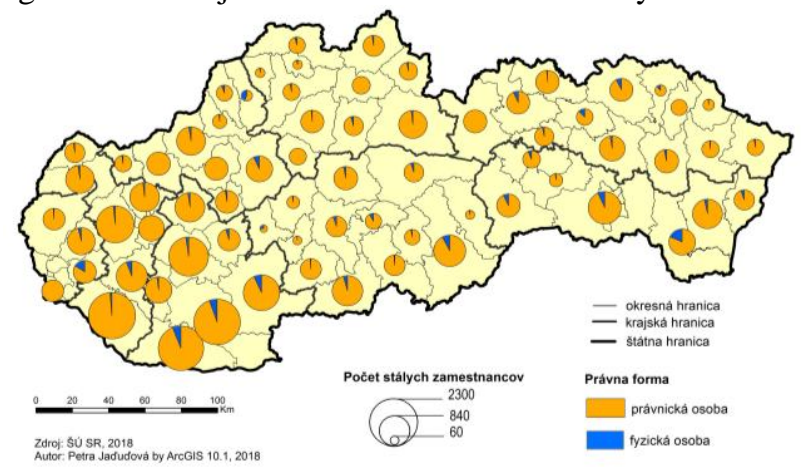

Mapa 3: Počet stálych zamestnancov podl'a právnej formy subjektu v okresoch Slovenska v roku 2016

Mapa 3: Number of permanent employees according to the legal status of agricultural subject in districts of Slovakia in year 2016

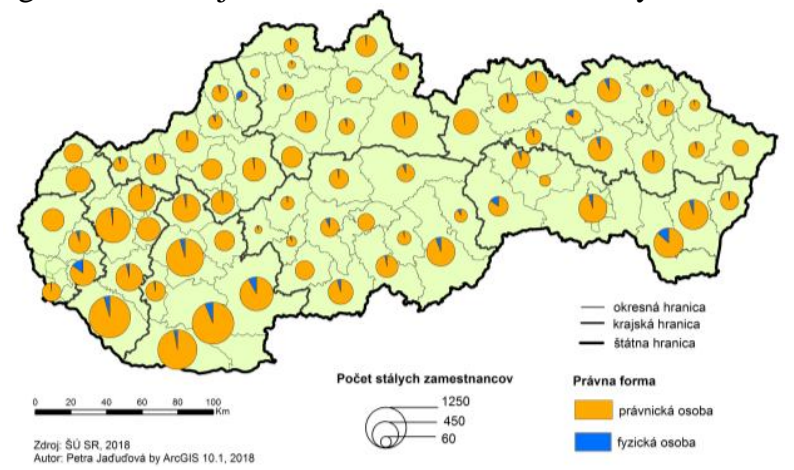


Za poklesom pracujúcich $\mathrm{v}$ agrárnom sektore je potrebné vidiet' množstvo nových technológií a inovácií, ktoré sa čoraz viac uplatňujú v pol'nohospodárstve, ale aj pôsobenie spoločnej pol'nohospodárskej politiky.

\section{Možnosti tvorby nových pracovných miest v pol’nohospodárstve}

V roku 2009 bol aj agrárny sektor postihnutý hospodárskou krízou a zaznamenal výraznejší záporný výsledok hospodárenia. Bol to prvý stratový rok pol'nohospodárstva od vstupu Slovenska do EÚ. K tomuto vývoju prispeli viaceré faktory, ale aj dôsledky svetovej hospodárskej krízy, prudký pád cien komodít, ktoré sa následne cez trhové systémy premietli aj do slovenského pol'nohospodárstva (Zelená správa, 2010). Pozitívne zmeny prinieslo obdobie po roku 2013. V roku 2014 podiel pol'nohospodárstva na zamestnanosti v národnom hospodárstve narástol na 3,26 \% (tab. 5) a rast pokračoval aj v roku 2015 (3,28 \%).

Tab. 5: Podiel pol'nohospodárstva na zamestnanosti v SR v rokoch 2008 - 2015 Table 5: Share of agriculture on employment in SR in the period 2008 - 2015

\begin{tabular}{|c|c|c|c|c|c|c|c|c|}
\hline \multirow{2}{*}{ Polnnohospodárstvo } & \multicolumn{9}{|c|}{ Rok } \\
\cline { 2 - 10 } & $\mathbf{2 0 0 8}$ & $\mathbf{2 0 0 9}$ & $\mathbf{2 0 1 0}$ & $\mathbf{2 0 1 1}$ & $\mathbf{2 0 1 2}$ & $\mathbf{2 0 1 3}$ & $\mathbf{2 0 1 4}$ & $\mathbf{2 0 1 5}$ \\
\hline podiel na zamestnanosti vNH $(\%)$ & 4,82 & 4,56 & 4,39 & 4,38 & 3,19 & 3,18 & 3,26 & 3,28 \\
\hline
\end{tabular}

Zdroj: Zelené správy (2012, 2014, 2016), 2017

Pozitívne zmeny v agrárnom sektore v posledných rokoch (2013 - 2016) sú vo vel'kej miere zapríčinené výsledkami opatrení na vytváranie pracovných príležitostí v rámci Programu rozvoja vidieka SR 2007 - 2013 (Buchta, 2015). Prostredníctvom SPP EÚ sú k dispozícií finančné prostriedky na pomoc mladým pol’nohospodárom pri zakladaní a rozvíjaní podnikania. Mladí farmári sa v súčasnosti môžu uchádzat' o nenávratný finančný príspevok v rámci podopatrenia 6.1 a získat štatút pol'nohospodára v rámci Programu rozvoja vidieka na roky 2014 2020 alebo $\mathrm{v}$ rámci podopatrenia 6.3 získat' finančnú pomoc na začatie podnikatel'skej činnosti. Je potrebné podporovat' generačnú obmenu pracovníkov v pol’nohospodárstve zvýhodnením projektov prispievajúcich $\mathrm{k}$ zlepšeniu vekovej štruktúry pracovníkov a podporovat' najmä mladých začínajúcich farmárov (Jamborová, Masár, 2015). Okrem finančných dotácií na podporu zamestnanosti v pol'nohospodárstve prispeli k rastu zamestnanosti mladých aj diverzifikácia výroby, ekologické pol'nohospodárstvo, finalizácia pol'nohospodárskych produktov a v neposlednom rade aj rozvoj agroturistiky. Podl'a Věžníka a Svobodovej (2008) aj v ČR je ohrozujúcim prvkom s výhl'adom do budúcna staršia veková štruktúra zamestnancov v pol'nohospodárstve. Zatraktívnenie pol'nohospodárstva a získanie mladších pracovníkov je dôležitou súčast'ou štrukturálnej politiky EÚ.

Vzhl'adom na podporu diverzifikácie pol'nohospodárskych podnikov, môžeme vidiet' na Slovensku, ale aj v iných štátoch Európy snahu o transformáciu 
pol'nohospodárstva na multifunkčné pol'nohospodárstvo. Spotrebitelia v súčasnosti čím d’alej tým viac uprednostňujú nákup pol’nohospodárskych produktov od domácich výrobcov, kde majú overenú ich kvalitu a hlavne pôvod. Potravinárske spracovanie vlastnoručne získaných plodín alebo živočíšnych produktov sa stáva viac rozšíreným na rodinných farmách. Takýmto spôsobom sa zvyšuje zamestnanost', životná úroveň vidieckych regiónov a konkurencieschopnost' domácich produktov, čo prispieva k pozitívnemu rozvoju regiónov (Tóthová, Fil'a, 2014).

Rozvoj vidieka a diverzifikácia pol'nohospodárskej výroby sú oblasti, do ktorých budú i $\mathrm{v}$ budúcnosti smerované prostriedky $\mathrm{z}$ finančných zdrojov Európskej únie. Vel'ké pol'nohospodárske subjekty sú zamerané najmä na pestovanie obilnín, olejnín alebo chov hospodárskych zvierat vo vel'kom počte, ale malí a rodinní farmári sa viac venujú špecializovanej rastlinnej a živočíšnej výrobe a tým prispievajú viac k diverzifikácii pol'nohospodárskej výroby. Európska únia vníma diverzifikáciu pol'nohospodárskej výroby nielen ako výhodu pre farmárov samotných, ale aj ako pridanú hodnotu pre ekonomiku vidieka a tvorbu nových pracovných miest. Pol'nohospodárstvo vníma ako oblast', ktorá je úzko spojená $\mathrm{s}$ potravinárskym priemyslom, turizmom a obchodom.

\section{Záver}

Pokles počtu pracovných síl v pol'nohospodárstve na Slovensku zodpovedá trendu vyspelých európskych štátov a súvisí s rastom technickej a technologickej vybavenosti výroby. K jeho priaznivým efektom patrí rast produktivity práce a znižovanie pracovných nákladov. K negatívnym dopadom patrí rast nezamestnanosti a t’ažkosti pri rekvalifikácii pracovníkov na iné pracovné pozície (Szabo, Grznár, 2015). Výrazný úbytok pracovníkov nastal v agrárnom sektore hlavne do roku 1999, potom bol pokles pracovníkov miernejší. Trh práce v SR sa neprispôsobil novovzniknutej situácii, ktorú priniesla transformácia pol'nohospodárstva a neposkytol prepusteným zamestnancom nové pracovné pozície, tým vznikla agrárna nezamestnanost'. Podl'a výsledkov ŠÚ SR v roku 2001 na Slovensku bolo trvale činných zamestnancov v pol'nohospodárstve 72 067, na dohodu pracovalo iba 707 osôb. Z hl'adiska hlavnej profesie prevládala profesia trvale činní robotníci v živočíšnej výrobe - 20414 pracovníkov.

Od vstupu Slovenska do Európskej únie sa spomalil medziročný pokles počtu zamestnancov. Podla údajov zo ŠÚ SR v roku 2010 bolo evidovaných trvale činných zamestnancov v pol’nohospodárstve spolu 31 685, oproti roku 2001 došlo $\mathrm{k}$ poklesu o $56,0 \%$. Z hl'adiska hlavnej profesie prevládala tiež profesia trvale činní robotníci v živočíšnej výrobe 8749 pracovníkov, čo predstavuje pokles oproti roku $2001(-57,1 \%)$. V roku 2015 pracovalo v pol'nohospodárstve 26861 trvale činných zamestnancov a na dohodu 13 681. Pretrvávajúci pokles zamestnancov bol zaznamenaný vo všetkých profesiách. V živočíšnej výrobe 
v roku 2015 pracovalo 7340 pracovníkov a v rastlinnej výrobe 5782 . V roku 2015 sú najpočetnejšími vekovými kategóriami pracujúci vo veku 55-59 rokov (20,0 \%) a 50-54 rokov (15,5\%). V porovnaní s rokom 2001 sa veková štruktúra obyvatel'stva zhoršila, o čom svedčí nižší podiel pracujúcich vo vekovej skupine 20-24 (2,8 \%). Pol'nohospodárska populácia aj v posledných rokoch starne a znižuje sa podiel zamestnancov v nižších vekových skupinách a na úkor toho pribúdajú vekové kategórie najstaršie. Zvyšuje sa aj priemerný vek zamestnancov, v roku 2014 bol 46,6 rokov. V porovnaní s rokmi 2001 a 2004, v roku 2010 výrazne poklesli zamestnanci s ukončeným základných vzdelaním a všeobecne sa zvýšila celková úroveň kvalifikácie zamestnancov agrárneho sektora. Najčastejšie právne formy subjektov v pol'nohospodárstve nad'alej zostávajú družstvá so $65 \%$ zamestnanost'ou a spol. s r.o. s viac ako $30 \%$. V rámci podpory zamestnanosti v pol'nohospodárstve bude potrebné podporovat' generačnú obmenu pracovníkov, zlepšovat' vekovú štruktúru pracovníkov a podporovat' najmä mladých začínajúcich farmárov. Podporné opatrenia EÚ priniesli možnosti nových pracovných miest, ktoré môžu na vidieku vzniknút, pričom najväčší potenciál je práve v diverzifikácii výrobnej štruktúry pol'nohospodárskych subjektov.

\section{Pod'akovanie}

Príspevok vznikol v rámci riešenia projektu VEGA 1/0934/17 „Transformácia využivania kultúrnej krajiny Slovenska za ostatných 250 rokov a predikcia jej d’alšieho vývoja".

\section{Literatúra}

BUČEK, J. - BORÁROSOVÁ Z. - SOPKULIAK, A. 2010. Miestne financie a miestny ekonomický rozvoj. Bratislava: Geo-grafika, 2010. 198 s. ISBN 97880-89317-12-7.

BUCHTA, S. 2013. Agrárna zamestnanost' a možnosti tvorby nových pracovných miest. In Ekonomika pol'nohospodárstva. ISSN 1338-6336, 2013, roč. 13, č. 2, s. 51-68.

BUCHTA, S. 2015. Agrárna zamestnanost' sa vlani prvý raz od roku 1989 zvýšila. In Slovo.sk [online]. [cit. 2018-03-14]. Dostupné na internete: <http://www.noveslovo.sk/c/Agrarna_zamestnanost_sa_vlani_prvy_raz_od_ro ku_1989_zvysila>.

INTERNÉ MATERIÁLY ŠTATISTICKÉHO ÚRADU SLOVENSKEJ REPUBLIKY. 2018. Bratislava.

JAMBOROVÁ, M. - MASÁR, I. 2015. Vývojové tendencie zamestnanosti v agrárnom sektore a v potravinárskej výrobe v poslednej dekáde (2005-2014) na Slovensku. In Ekonomika pol'nohospodárstva. ISSN 1338-6336, 2015, roč. 15, č. 4, s. 109-123. 
MINISTERSTVO PÔDOHOSPODÁRSTVA A ROZVOJA VIDIEKA SR. 2017. Správy o polnohospodárstve a potravinárstve $v S R$ (Zelené správy) za roky 2000 - 2016. Dostupné na internete: <http://www.mpsr.sk/index.php? navID $=122 \&$ ofs $1=0>$.

NÉMETHOVÁ, J. 2006. Geografické aspekty agrárnej zamestnanosti v agrosubjektoch okresu Nitra. In GEO Information. ISSN 1336-7234, 2006, roč. 3, č. 3, s. 53-63.

NÉMETHOVÁ, J. - DUBCOVÁ, A. - KRAMÁREKOVÁ, H. 2014. The impacts of the European Union's common agricultural policy on agriculture in Slovakia. In Moravian Geographical Reports. ISSN 1210-8812, 2014. vol. 22, no. 4, pp. 51-64.

ROZBORILOVÁ, E. 2012. Štrukturálny cenzus fariem 2010 - komplexné výsledky. Bratislava: Štatistický úrad Slovenskej republiky, 2012. 136 s. ISBN 978-808121-163-8.

SPIŠIAK, P. a kol. 2005. Agrorurálne štruktúry Slovenska po roku 1989. 1. vyd. Bratislava: Geo - grafika, 2005. 186 s. ISBN 80-969338-4-1.

SZABO, L. - GRZNÁR, M. 2015. Pracovné sily a výkonnost' pol'nohospodárstva v SR. In Ekonomika pol'nohospodárstva. ISSN 1338-6336, 2015, roč. 15, č. 3, s. 4-13.

ŠTATISTICKÝ ÚRAD SLOVENSKEJ REPUBLIKY. 2002. Štrukturálny cenzus fariem 2001 - Pracovné sily. Bratislava: Štatistický úrad SR, 2002. 13 s. ISBN 80-8058-300-5.

ŠTATISTICKÝ ÚRAD SLOVENSKEJ REPUBLIKY. 2017. Štruktúry zamestnancov $v$ pol'nohospodárstve 2004-2016. https://slovak.statistics.sk /wps/portal (2017-2-12)

TÓTHOVÁ, V. - FILA, M. 2014. Hodnotenie diverzifikácie pol'nohospodárskych subjektov v kontexte rozsahu obhospodarovanej pôdy. In Ekonomika pol'nohospodárstva. ISSN 1338-6336, 2014, roč. 14, č. 3, s. 69-81.

VĚŽNÍK, A. - SVOBODOVÁ, H. 2008. K problematice zemědělství na území MAS Boskovicko PLUS. In Geographia Cassoviensis. ISSN 1337-6748, 2008, roč. 2, č. 1, s. 195-200.

VĚŽNÍK, A. - SVOBODOVÁ, H. 2012. Vývoj zemědělství kraje Vysočina pod vlivem Společné Zemědělské politiky EU. In Geographia Cassoviensis. ISSN 1337-6748, 2012, roč. 6, č. 1, s. 81-92.

VĚŽNÍK, A. - SVOBODOVÁ, H. - NÉMETHOVÁ, J. - HRADICKÝ, J. 2017. Livestock production in Czechia and Slovakia, ten years beyond EU accession. In Human Geographies : Journal of Studies and Research in Human Geography. ISSN 1843-6587, 2017, vol. 11, no. 1, pp. 77-94.

WORLD BANK. 2018. Employment in agriculture. [cit. 2018-02-18]. www.data.worldbank.org/indicator/ 


\section{THE IMPACT OF AGRICULTURE TRANSFORMATION AND SLOVAKIA'S ACCESSION TO THE EU ON THE STRUCTURE OF LABOUR FORCE}

\section{Summary}

The decrease in the number of the labour force in agriculture in Slovakia corresponds to the trend of developed European states and it is associated with the growth of technical and technological equipment of production. Its beneficial effects include the growth in labour productivity and reduction of labour costs. Negative effects include the growth of unemployment and the difficulty in retraining workers for other occupations (Szabo, Grznár, 2015). The significant decrease of workers occurred in agricultural sector mainly till the year 1999, then a decline of workers was milder. The labour market in the Slovak Republic did not adapt to the new situation, which has brought the transformation of agriculture and has not offered laid-off employees a new job position. This created agricultural unemployment. According to the results of the Statistical Office of the Slovak Republic from the year 2001, , there were permanently employed staff of 72067 workers in the year 2001, while on the agreement there were only 707 persons. From the point of view of the main occupation, the permanently employed workers of animal production dominated with the number of 20414 workers.

Since Slovakia had entered the European Union, the year-on-year decrease in the number of employees slowed down. According to data from the Statistical Office of the Slovak Republic, from the year 2010, there were registered 31685 permanently employed staff in agriculture, compared to 2001 there was a decrease of $56.0 \%$. From the point of view of the main occupation, the permanently employed workers in animal production also dominated by the number of 8749 employees, but it also represents a decrease compared to the year $2001(-57.1 \%)$. In 2015, 26861 permanently employed workers worked together with 13681 people on the agreement in agriculture. A persistent decrease of employees was recorded in all the occupation. In animal production in the year 2015, there were 7340 workers and 5782 workers in crop production. The age category of 55-69 years old workers $(20.0 \%)$ was the most represented together with 50-54 years old people (15.5\%). In comparison with the year 2001, the age structure of the population has worsened, as evidenced by the lower share of the employed age group of 20-24 years old workers (2.8\%). In recent years, the agricultural population has been ageing and it is reducing the proportion of employees in the lower age groups and the increase of the oldest age categories. Also, the average age of employees is increasing, in 2014 it was 46.6 years. In comparison with the year 2001, in 2010 there was a significant decrease in employees with completed primary education, and generally assumed, the overall level of qualification of employees increased. The most common legal forms of agricultural subjects are 
still the cooperatives with $65 \%$ of employment and then the limited liability companies with more than $30 \%$. In support of the employment, it will be necessary to support the generational replacement of workers, to improve the age structure of workers and in particular, to encourage young start-up farmers. The support measures of the EU brought the possibility of new jobs, which may arise in the countryside with the greatest potential in the diversification of the farm production structure.

RNDr. Jana Némethová, PhD.

Bc. Petra Jad'ud'ová

Katedra geografie a regionálneho rozvoja FPV UKF v Nitre Trieda A. Hlinku 1, 94974 Nitra

E-mail: jnemethova@ukf.sk, petra.jadudova@student.ukf.sk 